\title{
MOVING INTO THE MAINSTREAM: AN ANALYSIS OF REGULATORY RESPONSES TO IMPACT ASSESSMENT IN EQUALITY AND SUSTAINABLE DEVELOPMENT
}

\author{
Victoria Jenkins (School of Law, Swansea University) and \\ Bernadette Rainey (Cardiff Law School)*
}

\begin{abstract}
Introduction
Equality and sustainable development present two of the most complex challenges for government in the 21 st century. The key to the achievement of these aims is the need to address discrimination and environmental damage in our society. The modern era of environmental protection and anti-discrimination legislation began in the 1970s with, for example, the Equal Pay Act 1970 and the Control of Pollution Act 1974. By the 1990s, however, the limits of this 'control and command' type legislation in both areas were clearly apparent, ${ }^{1}$ and a number of positive legal duties to promote sustainable development and equality of opportunity were introduced. ${ }^{2}$ These duties are important elements of a new approach to the implementation of 'cross-cutting' issues referred to as 'mainstreaming'. There are many examples of 'cross-cutting' issues such as social justice and rural poverty but the leading examples of the 'mainstreaming' initiative are found in relation to the issues of equality and sustainable development.
\end{abstract}

'Mainstreaming' involves ensuring that an objective, such as equality or sustainable development, is integrated into policy-making throughout an organisation. Policy impact assessment is arguably, the central tenet of an effective system of 'mainstreaming', although there are many structural issues that will affect its success. ${ }^{3}$ Early examples of policy impact

* The authors would like to thank Patrick Bishop, Swansea University, School of Law and Professor David Miers at Cardiff Law School for their comments on earlier drafts. Any errors are, of course, our own.

1 This term which is common in environmental law describes a process in which standards are put in place and subject to an ongoing process of regulation by an administrative agency. The basic tenets of such a system can also be seen to apply to anti-discrimination legislation. See further Wolfe and Stanley Principles of Environmental Law (2002) at 7-10.

2 E.g. the duty in the Race Relations (Amendment) Act 2000 to have due regard to the need to eliminate racial discrimination and promote equality of opportunity and good relations between people of different ethnic groups and the duty of the Environment Agency to contribute to the achievement of sustainable development. See generally on equality O' Cinneide Taking Equal Opportunities Seriously: the extension of positive duties to promote equality (2003) and on sustainable development Jenkins "Placing Sustainable Development at the Heart of Government in the UK: the role of law in the evolution of sustainable development as the central organising principle of government" (2002) 22(4) LS 578-601.

3 See further in the context of sustainable development for example, Ross "The UK Approach to Delivering Sustainable Development in Government: A Case Study 
assessment in both fields relied on 'soft law' mechanisms; the success of which relied on a strong system of political accountability in which decision makers would be held to account by senior managers and politicians. In practice, these regimes often failed to attract high level political support and were heavily criticised for a lack of accountability. In some instances however, accountability was achieved by a process of audit. The extension of audit as a mechanism of accountability from its traditional use in the financial sphere to the social and environmental context is well documented. ${ }^{4}$ The relative merits of such an approach have also been discussed, ${ }^{5}$ but the main difficulty in relation to the early examples of policy impact assessment was the quality of the audit process itself. In contrast, more recently moves have been made in the field of both equality and sustainable development to introduce a policy impact assessment regime in 'hard law.'

This paper will explore the nature and value of the regulatory response to impact assessment by considering two key examples - strategic environmental assessment (SEA) and equality impact assessment (EQIA). These two regimes emerged at different times and in very different circumstances. SEA was introduced by an EU Directive, in 2004, and involves environmental impact assessment of plans and programmes. It has however, been clearly linked to the achievement of sustainable development. ${ }^{6}$ It expands upon the existing regime for environmental impact assessment at project level (EIA), introduced in 1988, which was the first legal regime to attempt to regulate the discretion of decision makers. EQIA was introduced by the Northern Ireland Act 1998 as part of the process of devolution in the UK. This has consequently been elevated to a constitutional requirement. ${ }^{7}$

\section{Definitional Issues and Legal Approaches to Equality and Sustainable Development}

In defining equality a distinction has been made between the principle of equal treatment and that of equal opportunity. ${ }^{8}$ The principle of equal treatment is believed to underlie early anti-discrimination legislation that outlawed direct discrimination. The problems with this approach resulted in a new wave of action to tackle indirect discrimination under the principle of

in Joined-Up Working" (2005) 17(1) JEL 27-49 and Equal Opportunities Commission Mainstreaming Equality (2003).

4 Hollingsworth "Environmental Monitoring of Government - the Case for an Environmental Auditor" (2000) 20(2) LS 241-263, at 246.

5 Oliver Constitutional Reform in the UK (2003) at 54.

6 Art.1 Directive 2001/42 of the European Parliament and of the Council of 27 June 2001 on the assessment of the effects of certain plans and programmes on the environment states that its objective is "to provide for a high level of protection of the environment and to contribute to the integration of environmental considerations into the preparation adoption of plans and programmes with a view to promoting sustainable development".

7 See Robinson v Secretary of State for Northern Ireland [2002] 32, especially Lord Bingham and Lord Hoffman: The Northern Ireland Act 1998 is a constitutional document so must be interpreted against its background, i.e. the political situation in NI and the Good Friday Agreement

8 Fredman, The Future of Equality in Britain (2002), Chap.2. 
equality of opportunity. This concept is, arguably however, only useful if understood in a substantive sense that "requires measures to be taken to ensure that persons from all sections of society have a genuinely equal chance of satisfying the criteria for access to a particular social good." 9 Therefore, although anti-discrimination laws have made an important contribution to the achievement of equality, such laws have proved to be limited in many respects. Subsequently, calls have been made to provide a new concept of equality, integral to which is "the positive duty to promote equality, through such strategies as mainstreaming and positive action."10

The relationship between the notion of environmental protection and that of sustainable development is similar to that of discrimination and equality, in that early laws focusing on environmental protection have proved insufficient in moderating the relationship between humans and nature. Early environmental laws focused on the protection of the environment from the use of natural resources in human development and was characterised by a bid to plan the management of nature. ${ }^{11}$ Recognition of the limitations of this approach led to the search for new means to understand the relationship between development and environmental protection. This search ultimately resulted in the emergence of the concept of sustainable development. Sustainable development was originally defined by the World Commission on Environment and Development in 1987 as:

"Development that meets the needs of current generations without jeopardising the ability of future generations to meet their own needs." 12

The need to protect the environment is based on the principle of intergenerational equity. The sustainable use of environmental resources and control of pollution are fundamental to the achievement of sustainable development but it is argued that environmental sustainability can only be achieved by a careful balance of social, economic and environmental considerations. Sustainable development can, therefore, be viewed as an overarching aim of society that actually incorporates the need to achieve equality.

Equality and sustainable development are both controversial notions because they conflict with the basic values of liberty and modern economic concerns, yet there is also widespread agreement about their importance in modern society. ${ }^{13}$ They have both been described as proteon concepts and are clearly

9 Fredman Discrimination Law (2002) at 15.

10 Op. cit 8.

11 Winter "Perspectives for Environmental Law - Entering the Fourth Phase" (1989) 1(1) JEL $38-47$ at 40.

12 World Commission on Environment and Economic Development Our Common Future (1987). It is used as the key definition with the UK Government's national strategy for sustainable development Securing the Future: Delivering the UK Sustainable Development Strategy (2005) Cm. 6467.

13 Op. cit. 9 at 2 and 23-26. With regard to sustainable development, Redclift has noted that "'Sustainable development' remains a confused topic. Like motherhood and God, it is difficult not to approve of it. At the same time, 'sustainable development' is fraught with contradictions." Redclift M. and Sage C., Strategies for Sustainable Development: Local Agendas for the Southern Hemisphere, (1994) at 17. 
influenced by individual value judgements. ${ }^{14}$ Therefore, they are essentially contested concepts, which may be difficult to utilise in a legal environment in which definitional issues are paramount. ${ }^{15}$ Nevertheless, as outlined above, a number of positive legal duties exist in respect of equality and sustainable development. ${ }^{16}$ The nature of these duties has been considered in detail elsewhere. ${ }^{17}$ At the very least, these general duties are believed to have value as political statements which can be important in trying to engender the necessary culture change within a government office in order to achieve these aims. ${ }^{18}$ Nevertheless, this process is unlikely to be wholly successful without the support of an effective means of mainstreaming such objectives within the organisation. Therefore, it has been argued in the context of equality that general duties will be most effective where they are supported by specific legal requirements to support measurable policy impact assessment. ${ }^{19}$

\section{The Role of Policy Impact Assessment in Regulating Government Decision Making}

Equality and sustainable development are both described as 'cross-cutting' policy issues because they are not easily addressed by traditional approaches to policy making in departmental government. ${ }^{20}$ 'Joined-up government' is defined as:

"relating to, or designating a political strategy which seeks to co-ordinate the development and implementation of policies across government departments and agencies, especially with the aim of addressing complex social problems such as social exclusion and poverty in a comprehensive, integrated way." 21

Policy impact assessment (PIA) was considered to be an important tool in addressing "cross-cutting issues" and in 1999 the White Paper "Modernizing Government" made a commitment to introduce an integrated system of impact assessment and appraisal tools. ${ }^{22}$ However, PIA is widely considered

14 See for example the observations of Mcleod J. in the case of Fairlie "the concept of sustainability is comparatively new to the environmental field, is proteon in meaning and extremely difficult to define in any precise sense" Fairlie and others v SS for Environment and Another (1997) CA 12.05.97. The individuals making these values judgments are those whose judgments matter to the approach to equality and sustainable development: judges, politicians, government officials, international and non-government organisations etc.

15 See further op. cit. 2.

16 ibid.

17 ibid.

18 Jenkins op. cit. 2 and O' Cinneide "Positive Duties and Gender Equality" (2005) 8(1) IJDL 91-119.

19 O' Cinneide ibid., at 9.

20 During the 1990s the need for 'joined-up government' was central to the Labour government's agenda for modernizing government that was so prominent on its accession to power. See further Bogdanor Joined-Up Government (2005) at 178180.

21 Oxford English Dictionary quoted in Bogdanor ibid., at 1.

22 Modernizing Government (1999) Cm. 4310 at para.12. 
to be a necessary but not sufficient condition for mainstreaming. ${ }^{23}$ Such regimes need to be supported by other measures such as institutional structures, hence the UK government has both a Women and Equality Unit and Sustainable Development Unit in Whitehall. ${ }^{24}$ The aim of this paper however, is to focus more narrowly on the role of impact assessment as a tool within this process.

The process of PIA can provide an important mechanism for ensuring transparency, accountability and participation in government decision making, which are all key objectives of the Government's good governance agenda. ${ }^{25}$ The opportunities presented by PIA for ensuring public participation in government decision making also play a significant role in moving towards a model of participative democracy as another important element of recent constitutional reform in the UK. ${ }^{26}$ The system of PIA will clearly however, only achieve its objectives if it is applied in a systematic and effective way. This in turn presupposes an effective means of monitoring and accountability albeit public, political or legal.

\section{The Initial Response to PIA - A 'Soft Law' Approach}

Environmental policy appraisal (EPA) was originally introduced in 1990 in response to the UK's first environmental strategy - This Common Inheritance, ${ }^{27}$ and was later identified as an important element of the Conservative Government's strategy for sustainable development. ${ }^{28}$ On its accession to power, the Labour government continued this process by publishing a revised policy appraisal document. ${ }^{29}$ Furthermore, a Parliamentary Environmental Audit Committee (EAC) was established to scrutinise the policies and programmes of all departments of government to ensure that they were contributing to environmental protection and sustainable development, and to audit their performance against Ministerial

23 Nott "Accentuating the Positive: Alternative Strategies for Promoting Gender Equality" in Making Women Count (2000) 247-276 at 271.

24 See further Ross op. cit. 3 and Beveridge "Making Women Count" in ibid., 163190 at 185 .

25 Op. cit. 5 Chap. 3.

26 ibid., at 35-38. More recently discussion has focused on 'deliberative democracy'. This is described as a 'variant' of participatory democracy. "It envisages that citizens will actively discuss together and with officials the solutions to problems. The purpose again is to enable a learning process to take place in the citizenry that will improve understanding of the complexities of decisions that government has to take which will help legitimate decisions. Agreement on important values can also emerge from the process." Op. cit. 5 at 35.

27 Also introduced at this time was a network of 'green ministers' to provide a point of contact on environmental issues in all departments and a standing committee of cabinet ministers to consider how the issues raised in the White Paper should be taken forward. This Common Inheritance: Britain's Environmental Strategy (1990) Cmnd. 1200.

28 Sustainable Development: The UK Strategy Cm. 2426 (1994). This was a response to United Nations Conference on Environment and Development that created a global action for sustainable development - Agenda 21. This was to be supported by individual national action plans.

29 Policy Appraisal and the Environment (1998). 
targets. ${ }^{30}$ The existence of the EAC was widely heralded as an important development in efforts to ensure the success of this initiative, ${ }^{31}$ but has been criticised as follows:

"The EAC is ... providing a high level scrutiny role, as is befitting of a parliamentary committee. What it has not done is systematically review the extent to which individual departments are integrating the environment into policy making ..."

The EAC believes that this weakness in its role should be strengthened by the establishment of an Environmental Auditor General within the National Audit Office to mirror the arrangements for performance audit of public spending. ${ }^{32}$ This view is supported by academic opinion, but the UK Government's response was lukewarm. ${ }^{33}$

The first guidelines on Policy Appraisal and Equal Treatment (PAET) were also introduced in the UK in the 1990s. ${ }^{34}$ These guidelines outlined how the impact of policies on a wide number of disadvantaged groups should be considered but were not supported by any form of audit. ${ }^{35}$ The guidelines on PAET were introduced at the same time as the Northern Ireland guidelines on Policy Appraisal and Fair Treatment (PAFT), but the background to the introduction of PAFT is very different. The question of equality has consistently been a contested part of the political landscape of Northern Ireland since its creation in 1922. It is generally agreed that the recent conflict was in large part triggered by the discrimination suffered by the minority Catholic population, both in political and economic terms,${ }^{36}$ and the legislative response has traditionally focused primarily on political and religious discrimination in government and employment. PAFT followed the limited impact of measures such as the Fair Employment Act 1976 to address the inequality prevalent in the province. However, the guidelines on PAFT also addressed discrimination against a number of disadvantaged groups. It included a limited form of monitoring as an annual report by the Central Community Relations Unit. The lack of an effective monitoring regime and means of accountability under both PAFT and PAET was the subject of much criticism. ${ }^{37}$ On the failure of PAFT, strong calls were made for in the introduction of a regulatory response to this issue rather than a more

30 For further analysis of the work of the EAC see Ross "Greening Government Tales From the New sustainability Watchdog” (2000) 12(2) JEL 175-196. .

31 Op. cit. 4 at 245.

32 Environmental Audit: The First Parliament (Session 2000-2001) HC 67-I.

33 Government's response to the Environmental Audit Committee's Report on Environmental Audit: The First Parliament (2001). For further information on the academic debate see $o p$. cit. 4 .

34 For the most recent version see Policy Appraisal for Equal Treatment (1998).

35 Beveridge op. cit. 24.

36 See McKeever et al, "Thinking Globally, Acting Locally; Enforcing SocioEconomic Rights in Northern Ireland" [2004] Vol.2 EHRLR 166 and Ni Aolain The Politics of Force Conflict Management and State Violence in Northern Ireland (2000).

37 McCrudden "Equality" in Harvey Human Rights, Equality and Democratic Renewal in Northern Ireland (2001) 75-113 at 82 and op. cit. 23. 
effective means of monitoring and auditing progress. ${ }^{38}$ This resulted in the provisions of the Northern Ireland Act 1998 to be discussed below. ${ }^{39}$

As we move into the $21^{\text {st }}$ century, both the Northern Ireland and UK governments have begun to adopt an integrated approach to policy appraisal. As outlined above, in 1999 the White Paper on Modernizing government made a commitment to introduce an integrated system of impact assessment and appraisal tools. ${ }^{40}$ This initiative was specifically linked to the need to achieve sustainable development. ${ }^{41}$ Initially, this took the form of a 'policy makers' checklist' of impact assessment and appraisal tools, and sources of guidance. As outlined above, equality is an important element of the achievement of sustainable development, hence the sources of guidance included both EPA and PAET. ${ }^{42}$ A similar approach was adopted in Northern Ireland and the sources to be considered include reference to the statutory duties in relation to equality impact assessment under the Northern Ireland Act $1998 .^{43}$ More recently, as part of its revision of the sustainable development strategy, the Government has made moves to incorporate the system of integrated policy appraisal within the existing regime for Regulatory Impact Assessment (RIA).

Traditionally, RIA has measured only the financial costs and benefits of policy proposals, but the current advice provides that it should now be considered as the main tool for integrating sustainable development into central government policy. Hence, RIA must also always take into account the whole lifecycle costs, the human rights implications and an assessment of both the rural impacts and race equality impacts. Other assessments, such as reference to EPA, are decided on a case by case basis. ${ }^{44}$ There is a real danger, therefore, that, despite the new guidance, social and environmental considerations will simply be given lip service in the interests of economic efficiency. Indeed, the EAC has expressed serious doubts as to whether the system of RIA alone will ensure that "appraisal processes take sufficent

38 ibid., McCrudden at 86 .

39 More recently in line with developments in the EU, attention has focused on gender impact assessment. The EU has traditionally placed special emphasis on gender equality because equal treatment for men and women in respect of employment has been a key consideration of the EC since its inception in 1957. Equality more generally, and equality for men and women outside the occupational sphere, only surfaced within the EC Treaty in the late 1990s under the Treaty of Amsterdam. Current progress on gender mainstreaming is outlined in the Commission's framework strategy on gender equality Commission of the European Communities Towards a Community Framework Strategy on Gender Equality (2001-2005).

40 Op. cit. 22 at para. 12.

41 ibid.

42 The list covered sustainable development; scientific evidence; risk; the Human Rights Act; the EU dimension; regulatory impact assessment; environmental appraisal; rural proofing; equal treatment; health; health and safety and consumer impact. Policy Makers Checklist: Using Impact Assessment and Appraisal - A Toolkit (1999).

43 Integrated Impact Assessment in Northern Ireland available at http://www.ofmdfmni.gov.uk/iia.

44 Checklist for Policy Makers (2005). 
account of environmental priorities. ${ }^{45}$ Nevertheless, the system of RIA has an effective monitoring regime with scrutiny by both the Better Regulation Executive within the Cabinet Office ${ }^{46}$ and the National Audit Office.

\section{The Regulatory Response to Impact Assessment: Strategic Environmental Assessment (SEA) and Equality Impact Assessment (EQIA)}

\section{$S E A$}

The SEA regime was introduced in the UK in response to an EU Directive. The central tenets of the systems of environmental impact assessment under this regime are as follows:

- The regulations apply to plans and programmes that set the framework for future development consents. There are two categories of such plans and programmes. If the framework created by the plan or programme relates to development consents for a project listed in the Directive, an environmental impact assessment is mandatory. If the framework created by the plan or programme relates to any other type of project, an assessment is only required if the project is "likely to have significant effects on the environment." 47

- Where an impact assessment is required it takes the form of an environmental statement identifying, describing and evaluating the likely significant effects on the environment of the project, plan or programme and reasonable alternatives. ${ }^{48}$

- The draft environmental report must be the subject of consultation with the public and environmental authorities. ${ }^{49}$

- The environmental report and all results of the consultation must be taken into account before a decision is made on a project. ${ }^{50}$

The SEA regime is, in fact, an extension of the regime for environmental impact assessment (EIA) that is carried out at project level and was first introduced in 1988. ${ }^{51}$ At this time, EIA was considered to be a unique form

45 The Sustainable Development Strategy: Illusion or Reality? Session 2003-2004 Vol.1 HC 624-I P.37 at 38.

46 The name of this unit has changed many times most recently, in May 2005, from the Regulatory Impact Unit to the BRE. However, the remit has remained largely the same and dates back to the creation of the Deregulation Unit under the Conservative Government's drive to reduce legislative burdens on small businesses and increase competitiveness during the 1980s.

47 Art.5 Environmental Assessment of Plans and Programmes Regulations 2004 SI 1633. These regulations are accompanied by non-statutory guidance - OPDM $A$ Practical Guide to the Strategic Environmental Assessment Directive (OPDM, 2005).

48 ibid., art.12.

49 ibid., art.6.

50 ibid., art.8.

51 The original EIA Directive, negotiations on which actually started in the late 1970 's, was inspired by the introduction of EIA under the National Environmental Policy Act 1969 in the USA. Interestingly, the first draft of the Directive applied 
of regulation setting out as it does a procedure for decision making. ${ }^{52}$ It was not without controversy in the UK and was implemented largely through the planning system. ${ }^{53}$ Procedurally, the most important difference is that the statement of environmental impacts is produced by the developer, a private interest. It has been argued that in case of EIA, where the person creating the environmental statement is a developer, and that person has a great deal of discretion in doing so, the process can actually serve to legitimize their interests. In the process of policy assessment the person creating the statement is the public authority, which may have as much interest in legitimizing its position and is now both information gatherer and decision maker. Furthermore, SEA itself is not strictly a form of policy impact assessment as in the example of EQIA. The differences between policies, plans and programmes have been identified as follows:

"The policy is the inspiration and guidance for action, the plan provides for the co-ordination and timing of objectives and the programme sets out the projects to be implemented."

The differences between policies and projects are even greater:

"In practice ... policies and projects do differ in terms of the wider ranging impacts from policies compared to projects, the greater uncertainty of policy impacts, and the probable smaller chance of being able to quantify policy impacts. In turn, if policies go wrong they are likely to have wider impacts

not just to projects but policies, plans and programmes. This was met with considerable political pressure and, hence, the final version applied only to projects. As a result, the focus of the Directive is on land-use and spatial planning. Almost as soon as the original Directive on EIA was passed, the Commission continued to push for an extension of EIA to policies, plans and programmes. This was considered to be a logical extension of EIA that was, by its very nature, reactionary, and failed to adequately consider the cumulative impacts of projects or the issue of alternatives. Once more the original SEA Directive was drafted to include policy impact assessment, but succumbed to political pressure. See further Sheate "From Environmental Impact Assessment to Strategic Environmental Assessment: Sustainability and Decision Making" in Holder The Impact of EC Environmental Law in the UK (1997).

52 Holder Environmental Impact Assessment: The Regulation of Decision Making (2004) at 244.

53 Council Directive 85/337 on the Assessment of the Effects of Certain Public and Private Projects on the Environment. See further Zetter Environmental Impact Assessment: Has it had an Impact? in Holder op. cit. 51. The original EIA Directive was amended in 1998 to deal with some of the difficulties that arose in the relation to the original Directive and to comply with the EU's accession to the Aarhus convention on public participation and access to justice. Council Directive 97/11 amending Directive 85/337 on the assessment of the effects of certain public and private projects on the environment and Directive 2003/35 providing for pubic participation in respect of the drawing up of certain plans and programmes relating to the environment and amending with regard to public participation and access to justice Council Directives 85/337 and 96/61. The EIA Directive is therefore, currently implemented by the Town and Country Planning (Environmental Impact Assessment) (England and Wales) Regulations 1999 SI 293. Guidance on the procedures is found in Circular 02/99. 
whereas projects . . . may fail and not have major feedback effects . ..." ${ }^{, 5}$

However, all these forms of impact assessment use similar techniques and, indeed, the problems that have been encountered in implementing SEA and project impact assessment are recognised to be very similar. ${ }^{55}$

\section{EQIA}

The failure of the PAFT guidelines to have a real impact on government policy-making, as outlined above, was influential in calls for the negotiations for a political settlement to include rights and equality as essential constituents for any agreement. ${ }^{56}$ The Northern Ireland Act 1998 subsequently included a duty to promote equality of opportunity that became applicable from $1^{\text {st }}$ January $2000 .{ }^{57}$ It is arguably the most advanced form of 'mainstreaming' equality within the UK, and shifts the emphasis from addressing individual discrimination to focusing on the societal impact of inequality against a background of division and conflict.

Section 75 (1) of the Northern Ireland Act 1998 provides that a public authority shall, in carrying out its functions relating to Northern Ireland, have due regard to the need to promote equality of opportunity:

- between persons of different religious belief, political opinion, racial group, age, marital status or sexual orientation;

- between men and women generally;

- between persons with a disability and persons without; and

- between persons with dependants and persons without"

The implementation of this general duty is outlined in Schedule 9 of the 1998 Act. Under the schedule a public authority is under a duty to produce an equality scheme, which is then submitted to the Equality Commission for approval..$^{58}$ The scheme must demonstrate how the authority proposes to fulfil the duty imposed by section 75 of the Act, including, inter alia, the arrangements for assessing and consulting on the likely impact of policies adopted or proposed. ${ }^{59}$ The requirements of the legislation are reinforced by statutory guidelines from the Equality Commission. ${ }^{60}$

54 Review of Technical Guidance on Environmental Appraisal at para.2.

55 Glasson et al Introduction to EIA: Principles and procedures - process, practice and prospects (1994).

56 Examples of polices that were affected by a PAFT appraisal were limited. See further Hadden et al "Equal But Not Separate: Communal Policy Appraisal" (1998) Fortnight supplement 371.

57 Northern Ireland Act 1998.

58 ibid., sch.9, para.2, 3.

59 ibid., sch.9 para.4 (b).

60 Equality Commission for Northern Ireland Section 75 of the Northern Ireland Act 1998: Guide to the Statutory Duties (2005). The Equality Commission is responsible for monitoring the implementation of the non-discrimination legislation as well as the statutory duties. 


\section{Regulatory Responses to Impact Assessment: Developing an Analytical Framework}

In assessing the regulatory response to impact assessment this paper will consider the potential success of the enforcement mechanisms associated with these legal regimes in ensuring the proper application of the law. However, the success of these regimes also depends upon the development of an effective framework for impact assessment in the first place. There are five key issues to consider in this respect - the political environment; screening and scoping; staff training; consultation; and, transparency and monitoring.

\section{The Political Context}

PIA is a complex process in which the person carrying out the process maintains a great deal of discretion. Furthermore, any legal regime for impact assessment does not operate in a vacuum but is heavily influenced by the political environment. Guidelines, statutory or otherwise, can lay down the assessment procedure to be followed by the assessor but even if the assessor carries out all the steps laid down the quality of decision making cannot be assured. In other words, there is always a danger that the process will simply become a 'tick and bash' procedure. ${ }^{61}$ Paradoxically, the impact assessment procedure itself can act as an important means of bringing about the 'culture change' necessary to avoid this. ${ }^{62}$ There are certain elements of the regime that are particularly important in engendering this culture change such as providing a clear objective.

As outlined above, both equality of opportunity and sustainable development are inherently difficult to define. The following section on compliance and enforcement will highlight the difficulties that have been encountered in attempting to adjudicate the meaning of equality of opportunity in the context of section 75 of the Northern Ireland Act 1998. ${ }^{63}$ The EU Directive on SEA states that its objective is "to provide for a high level of protection of the environment and to contribute to the integration of environmental considerations into the preparation and adoption of plans and programmes with a view to promoting sustainable development" ${ }^{64}$ There is nevertheless, some academic disagreement as to the effectiveness of SEA as a tool for

61 Rees Mainstreaming equality in the European Union: education, training and labour market policies (1998) at 191-192.

62 Op. cit. 52 at 282.

63 Some attempt to has been made to analyse the concept in this context by McCrudden who concludes that "the concept of equality of opportunity in section 75 , as interpreted by the authoritative statutory body and consistent with the approach to the meaning of equality of opportunity in other areas of Northern Ireland and EC law, ... incorporates but goes beyond any of the limited concepts of discrimination ... section 75 involves not only a duty ... to eliminate discrimination ... but actively to take steps to promote greater equality of opportunity." McCrudden "Mainstreaming Equality in Northern Ireland 19982004: A Review of Issues Concerning the Operation of the Equality Duty in section 75 of the Northern Ireland Act 1998 in McLaughlin and Faris, The Section 75 Equality Duty - An Operational Review Vol.1 (2004) at 18-19.

64 Op. cit. 6. 
achieving sustainable development. ${ }^{65}$ However, the procedural objective of the SEA regime in identifying and describing the environmental impacts of a plan or programme are undoubtedly easier to deal with in definitional terms than the objective of sustainable development.

\section{Screening and Scoping}

There are two key stages in the process of impact assessment - screening and scoping.

In any system of impact assessment, for reasons of practicality, there has to be a system of screening to identify the projects, plans, programmes or policies that are most likely to have a significant impact. Nevertheless, the screening process creates an obvious avenue for abuse of the system:

"Public authorities might take advantage of this to evade impact assessments of the most difficult issues, or might screen out policies simply because they did not identify any problem that needed to be considered further because of the absence of statistical data, even when others would." ${ }_{66}$

Scoping refers to the content of the impact assessment report after screening has revealed a report is needed and this is crucial to the process of environmental assessment. The statement should provide good quality information on environmental/equality impacts that specifically discusses alternative options and, indeed, the possibility of no action. Where negative impacts are found it should also provide details of the measures that can be taken to mitigate these.

Providing the right level of detail in relation to the processes of screening and scoping is a difficult issue. Both the PAET guidlines and guidance on EPA were revised to reduce the level of detailed advice. In the case of PAET this has been described as lamentable, ${ }^{67}$ but in the case of EPA it has been welcomed. With regard to EPA, it was felt that less detailed guidance was more appropriate for senior management that require "a robust yet more impressionistic account of environmental impacts of policy measures." 68 In developing a regulatory response to PIA, a careful balance must be achieved between the need for clear guidance as to how to assess key impacts and concerns to avoid "the imposition of excessive, alienating and throttling bureaucratic requirements." ${ }^{\circ 9}$ Also important in this respect is the quality of staff training to ensure that the guidance is used and applied effectively.

65 Glasson et al believe that "SEA is . . . likely to be one of the most direct and effective ways of ensuring that human activities are carried out at a level that is environmentally sustainable over time." Op. cit. 55 at 313 . However, Therivel et al believe that the system of SEA will result simply in the extension of green policies rather than ensuring that sustainable development is considered to be the central objective in all plans and programmes Therivel et al Strategic Environmental Assessment (1992). The OPDM guidance on SEA does not address this question but does provide some information on the nature of the concept of sustainable development op cit 47 at 20.

66 Op. cit. 63 at 8.

67 Op. cit. 23 at 266.

68 DETR Review of Technical Guidance on Environmental Appraisal (1999).

69 Op. cit. 18 at 9. 


\section{Screening}

The approach in SEA is to produce lists of plans and programmes for which assessment is mandatory but to subject others to a test of "likely significant effects on the environment." The latter is very difficult because it basically requires a preliminary assessment of the effects of a measure. There are a number of detailed criteria laid out in the regulations which must always be taken into account in carrying out the screening process, ${ }^{70}$ but no further details are provided in the guide to SEA. ${ }^{71}$

With reference to EQIA the guidance states that all policies are to be screened in order "to identify those policies that are likely to have a significant impact on equality of opportunity so that greatest resources can be devoted to these." ${ }^{\prime 2}$ It includes both mandatory screening criteria and suggests the use of indicators in making such decisions. These set out four questions that must be asked:

- is there any indication or evidence of higher or lower participation or uptake by different groups?

- is there any indication that different groups have different needs, experiences, issues and priorities in relation to the policy?

- is there any indication that previous consultations indicate particular policies create problems specific to them?

- is there an opportunity to better promote equality by altering the policy?

If the answer to any of these is yes, the authority must consider if the policy should be subject to an EQIA. ${ }^{73}$ The circular on EIA also includes indicative criteria and thresholds that provide broad indications of the type or scale of development that is likely to fall within the definition. The experience here demonstrates the problems associated with this approach as the original thresholds had to be revised following allegations that some were arbitrary and/or set very high. ${ }^{74}$

In fact the most difficult questions in respect of the initial stages of the EQIA process have been experienced in identifying "which parts of a designated

70 S.9(2) and Sch.1 op cit 47. These criteria focus on the characteristics of and plans and programmes themselves, including the relevance of the plan or programe for the integration of environmental considerations in particular with a view to promoting sustainable development. It also includes the effects, such as the risks to human health, and the cumulative nature of the effects; the area likely to affected, such as the magnitude and spatial extent of the effects; and the value and vulnerbility of the area due to special natural characteristics/cultural heritage, the excession of environmental quality standards or limit values and intensive land use.

71 Op. cit. 47.

72 Op. cit. 60 S.4, para.3(a).

73 S.4, para 3(a) (ii) ibid.

74 See further Circular 02/99 op. cit. 53 and Moore, A Practical Approach to Planning Law (2000) at 244. This circular was in fact revised when the original EIA Directive was amended but despite the subsequent changes problems still remain. See further Stookes "Getting to the Real EIA" (2003) JEL 15(2) 141151 at 147. 
public authority's work constitute 'a policy' for the purposes of section 75"75 and then prioritising those to be screened. The guidance gives criteria for prioritising the policies for assessment including social need, effect on daily lives, effect on economic, social and human rights, effect on expenditure and strategic importance. ${ }^{76}$ This outline refers to the second version of statutory guidance provided. In fact, the poor quality of the initial guidance on screening was identified as a key problem in this regime.

\section{Scoping}

A major criticism of the PAFT guidelines was the undefined nature of the scope of any equality assessment carried out by the authority. Hence, schedule 9 of the 1998 Act provides authorities with a duty to state the aims of the assessed policy and give details of consideration given to measures to mitigate any adverse impact on equality of opportunity and to alternative polices which might better achieve promotion of equality of opportunity. ${ }^{77}$ There is also clear duty under the 1998 Act for the authority to take into account any equality impact assessment in its policy decision making. ${ }^{78}$ The statutory guidance details what this means in practice. Clear evidence must be provided of its consideration of mitigation of adverse impact or alternative policies where adverse effects have been identified. Recommendations on impact assessments must also justify decisions not to mitigate impact or devise alternate polices. The authority must also give reasons where no adverse impacts have been identified and must continue to monitor the policy. ${ }^{79}$

The regulations on SEA provide a general duty to identify, describe and evaluate the likely significant effects on the environment of implementing the plan or programme and reasonable alternatives, with a more detailed list of criteria whose use is discretionary. ${ }^{80}$ The environmental report and all results of the consultation on the draft plan or programme must be taken into account during its preparation and before its adoption or submission to the legislative procedure. ${ }^{81}$ It has been noted in relation to the EIA regime, that at the moment no special 'weight' is given to the environmental information provided by the environmental assessment process which is also true of SEA. ${ }^{82}$ The EU Commission has proposed that the EIA Directive could be amended to oblige authorities to refuse a project that could cause significant environmental damage but also recognise that this would be "politically controversial and potentially contrary to the subsidiarity principle." 83

75 See McLaughlin and Faris The Section 75 Equality Duty - An Operational Review Vol.1 (2004) Chap.2.

76 S.4 para.4 (a) (iii) op. cit. 60.

77 Sch.9 para.9 (1) (a) op. cit. 57.

78 Sch.9 para.9(2) ibid.

79 Annex 1 para.6 op.cit. 60.

80 S.12 and Sch.2 op . cit. 47

81 S.8(3) ibid.

82 Op. cit. 52 at 267.

83 ibid., at 208. 


\section{Staff training}

The EQIA regime includes a duty for authorities to make provision for staff training in their equality schemes, and given the remit of the scheme this will necessarily include training in respect of impact assessment. This raises this practical requirement for a successful PIA process to the level of a statutory duty ${ }^{84}$ Unfortunately, there is no such requirement in relation to SEA.

\section{Consultation}

There are broadly two models of impact assessment that have been described in the context of gender mainstreaming. The expert-bureaucratic approach views the assessment process simply as a procedure to be carried out by policy makers or other experts in the field whilst the participatorydemocratic approach focuses on the importance of participation. ${ }^{85}$

Early regimes such as EPA, PAET and PAFT did not include any reference to consultation in the PIA process, ${ }^{86}$ but this has since been recognised as key to the consideration of policy impacts. In the environmental context, it is argued that, participation can lead to better decision-making as well as building public confidence in those decisions. ${ }^{87}$ Participation is also important in the environmental field because many decisions are based on uncertain scientific evidence, e.g. assessing the level at which air pollution becomes dangerous. ${ }^{88}$ Scientific knowledge is not an issue in considering the reasons for participation in decisions relating to equality, but here it may be argued that those best placed to comment on the discriminatory impacts of new policies are people within the disadvantaged groups themselves. Furthermore, it is arguable that the involvement of such groups in creating policy also contributes to the inherent goal of their empowerment. ${ }^{89}$

It is vital that participation in the process of decision making is meaningful because there is a danger that it may legitimate a process which might otherwise be considered to have little merit:

"Participative decision making also contributes to trust being placed in those decisions, although from a critical perspective this raises the issue of undue legitimacy or symbolic reassurance via proceduralization." 90

However, a number of difficulties arise in ensuring an effective consultation process. A key issue is the capacity of individuals, voluntary and community

${ }_{85}^{84}$ Sch.9 para.4(b) op. cit. 57.

85 Op. cit. 23 at 269.

86 See, e.g. on PAFT op. cit. 56 and McCrudden "Mainstreaming Fairness?' A Discussion Paper on Policy Appraisal and Fair Treatment" (1996).

87 Steele "Participation and Deliberation in Environmental Law: Exploring a Problem Solving Approach" (2001) OJLS 21(3) 415-442.

88 Environmental policy in the UK dictates that such issues should be dealt with according to the precautionary principle, i.e. that if the effects of an activity are unknown it should not be undertaken. This is one of several principles in the environmental field that have been adopted as legal principles within the EU. See further Macrory Principles of European Environmental Law (2004).

89 Op. cit. 23 at 270.

90 Op. cit. 52 at 196. 
groups to respond to the consultative process in terms of time and resources (both financial and intellectual). Furthermore, the process of consultation also raises expectations which may not be met in all circumstances.

In the SEA regime, environmental authorities must be consulted in the screening processs on any case by case examination. The authority also has a duty to consult environmental authorities on the scope and level of detail of the information in the screening report. ${ }^{91}$ However, controversially, there is no obligation for the responsible authority to involve the public at this stage. ${ }^{92}$ Nevertheless, once in draft, the plan or programme and the environmental report must be made available to the public and the environmental authorities, ${ }^{93}$ and the consultees and the public must be given "an effective opportunity to express their opinion on the documents." 94 The original EIA Directive was heavily criticised for a lack of genuine commitment to effective consultation and in comparison, the requirements of the SEA regime are a great improvement. ${ }^{95}$

The need for consultation has also been identified as an important constituent of the equality agenda in Northern Ireland. ${ }^{96}$ The guidance on EQIA states that the screening process must include consultation with relevant groups ${ }^{97}$ and the Act itself provides the authority with a duty to make arrangements for assessing and consulting on the impact of policies in the scoping process. ${ }^{98}$ The latter must include relevant interest groups as well as the Equality Commission, other public bodies, voluntary, community, trades union and other groups with a legitimate interest in the matter. Perhaps most importantly, this must include those "directly affected" by the policy to be assessed, "whether or not they have a direct economic or personal interest." Early research into the operation of section 75 highlighted a culture of participation being adopted with the creation of formal links between government and civil society. ${ }^{99}$ However, the perennial difficulties with consultation outlined above have surfaced in this context. The main concerns involve capacity, expectation and funding. ${ }^{100}$ Whether or not both

91 S.12 (5) op. cit. 47.

92 ibid.

93 S.13 ibid.

94 S.13(3) ibid.

95 Op. cit. 74 at 150.

96 See further op. cit. 96 .

97 Op. cit. 60 at 62.

98 Sch.9 para.4 (2) op. cit. 57.

99 Donaghy 'Mainstreaming: Northern Ireland's participative-democratic approach" Policy and Politics 200432 (1) 48-62.

100 There is a shortage of resources and capacity among voluntary and community groups who represent the equality duty groups, with some being overwhelmed by the consultation documents they receive. Others complained that public bodies rely on too few groups, quantitative instead of qualitative indicators and do not give enough feedback to consultees. Public bodies noted that some groups expect too much from consultation or fail to respond when detailed consultation is put in place. See McLaughlin and Faris The Section 75 Equality Duty - An Operational Review Vol 1 (2004) at para.6.4 and Equality Commission Report on the implementation of the Section 75 Equality and Good Relations Duties by Public Authorities (1 April 2003 - March 2004) at 12. There is also a lack of funding for consultees op. cit. 99 . In response to this a recent task force 
the SEA and EQIA regimes represent a democratic/participative model is a difficult question, and has only been the subject of academic debate in the context of EQIA. In fact, they are probably both best viewed as a combination of the two. ${ }^{101}$

\section{Transparency and Monitoring}

The provisions for both transparency and monitoring are important in holding decision makers to account for their actions. As outlined above, transparency is an important element of good governance and is necessary to ensure that those affected are aware of decisions made. Under the SEA regime, when the plan or programme is adopted the authorities and the public must be informed and the plan or programme made available to them. ${ }^{102}$ Equally, in relation to EQIA, authorities are required by the 1998 Act and the guidance to publish their decisions including possible alternatives and any consideration of measures which might mitigate any adverse impacts. ${ }^{103}$ The duty to provide reasons for the authorities' decisions also extends to screening decisions under EIA/SEA and EQIA. ${ }^{104}$

There are two key aspects in respect of monitoring. The first is post-project monitoring which is considered vital to the process of "culture change" within an organisation by "encouraging learning through feedback loops."105 This is an essential element of equality impact assessment in Northern Ireland and public authorities must publish their reports in this regard. ${ }^{106}$ The statutory guidance provides that a system must be established to carry out ongoing monitoring of the impact of policies and the results should be reviewed on an annual basis. If the monitoring over a two year period demonstrates that the policy results in greater adverse impact than was predicted, or opportunities arise allowing for greater equality of opportunity, then the policy must be revised. ${ }^{107}$ Similarly, under the regime for SEA, authorities have a duty to monitor the significant environmental effects of the implementation of plans and programmes subject to impact assessment in order, inter alia, to identify at an early stage unforeseen adverse effects and to be able to undertake appropriate remedial action. ${ }^{108}$

recommended a ten year plan to improve community/voluntary sector capacity including streamed funding from government. It has also been recommended that public bodies and groups approach consultation strategically with groups improving capacity by working together at targeting areas. See Investing Together: Report of the Task Force on Resourcing the Voluntary and Community Sector (2004). Available from www.taskforcevcsni.gov.uk.

101 These models, as outlined above, were developed by Nott. She believes that s.75 represents a democratic/participative model op. cit. 23. However, Harvey has argued that it is in fact a combination of the two. Harvey "Governing After the Rights Revolution" (2000) JLS 27 61-97.

102 S.16 op. cit. 47.

103 Sch. 9 paras.9(1) and 4(2) (d) op. cit. 57.

104 S.9 op. cit. 47 and s.4 op. cit. 60.

105 Op. cit. 52 at 289.

106 Sch.9 para 4 (c) op. cit. 57.

107 Annex 1 paras.7.1-7.2 op. cit. 60.

108 S.17 (1) op. cit. 47. 
The second and perhaps most important aspect of monitoring relates to the quality of impact assessment reports. This study focuses on accountability in the procedural context but it is only by monitoring the quality of impact statements that we can seek to ensure the substantive quality of the process. The EU Commission has a role in monitoring progress on SEA by receiving reports from the Member States on measures they have taken to ensure that environmental reports are of sufficient quality. ${ }^{109}$ The guidance to planning authorities also includes a quality assurance checklist to be used by authorities who carry out SEA, organisations that they consult, inspectors, auditors, independent experts, and members of the public but suggests nothing further regarding the monitoring of the quality of environmental reports. 110

With regard to equality, the Equality Commission was given responsibility to monitor the statutory duty under the Northern Ireland Act. ${ }^{111}$ The central mechanism for this is its duty to formally approve all equality schemes and for public authorities to submit an annual report to the Equality Commission. ${ }^{12}$ The Equality Commission also has to produce an annual report on the statutory duties and review progress on the implementation of the statutory duties every five years. ${ }^{113}$ As a statutory consultee, the Equality Commission also has an important role to play in the process of EQIA, not just procedurally but also substantively. It has issued practical guidance on the EQIA, offering non-statutory guidance as well as building up a database of good practice. Nevertheless, the Equality Commission does not formally monitor the quality of impact assessments. It has been suggested in the environmental context that we should have an independent commission to "oversee the compilation and evaluation of environmental statements." 114 However, the Government has stated that:

"The Government has no plans to create a dedicated body to carry out or oversee SEAs. In general, we believe the best approach is to integrate this role into the overall arrangements for oversight of plans or programmes. We are developing methods for quality assurance as part of a foundation of good practice." 115

109 Article 12(2) op. cit. 6.

110 OPDM guidance op. cit. 47 at 54.

111 Under the Act, the equality commission shall keep the effectiveness of the S.75 duties under review, offer advice to authorities and others and carry out designated functions. Sch.9 para.1 op. cit. 57.

112 Sch.9 paras. 2 and 3 op. cit. 57. The Secretary of State can either approve the scheme or direct the Authority to revise the scheme (again informing the Assembly) (Sch.9 paras.6-7 op. cit. 57). The duty with regard to an annual report is found in the statutory guidance (Chap.4, para.4.16, op. cit. 60).

113 The annual report is sent to the department of Economic development and then laid before the Assembly and the Secretary of State and through the Secretary of State, the report shall be laid before parliament (Schedule 8 op cit 57). Provision for the annual review is found in the Northern Ireland Act (Sch.9 para.8(3) op. cit. 57).

114 Op. cit. 52 at 296.

115 OPDM guidance op. cit. 47. 


\section{Conclusions}

This discussion of the legal frameworks for SEA and EQIA in the light of previous experience with 'soft law' approaches and EIA suggests that it is possible to provide a 'best practice' model of impact assessment that would "work" in any context. The key elements are:

- A clear objective with definitional clarity

- Detailed guidance with regard to both screening and scoping

- Provision for staff training

- Provision for consultation

- Ensuring transparency in the process

- Monitoring of the quality of assessments and post-project monitoring

The key elements are similar whether applied at project, plan, programme or policy level, but the latter perhaps presents the biggest challenge because of the complex nature of policy making and number of assessments to be carried out. Any difficulties may however, be overcome by providing clear guidance on the definition of a policy and how to prioritise the policies to be screened.

The legal frameworks for SEA and EQIA have, to a large extent, addressed many of the problems associated with the non-statutory regimes for impact assessment and those identified under the EIA regime. A major issue however, is the lack of monitoring in respect of the quality of impact statements. As stated above, this is clearly very important in any qualitative assessment of the process, but it is also very resource intensive and hence, politically unpopular. The remainder of this paper will discuss the success of a legal strategy for the enforcement of these provisions in providing accountability in the procedural context.

\section{Compliance and Enforcement}

The SEA and EQIA regimes both create enforceable provisions that can be the subject of court action. However, given their recent introduction, there are still relatively few cases on EQIA and none to date on SEA. Therefore, this section will also consider the extensive experience of litigation in respect of the EIA regime in so far as it is relevant. The system of EQIA is also supported by a further compliance mechanism under which the Equality Commission is given the power to undertake its own investigations and hear complaints from individuals. This has proved very significant in ensuring accountability in the process.

\section{Judicial Review Cases}

\section{Environmental Impact Assessment}

The case law on EIA is well documented. It is sufficent therefore, to highlight a few of the salient points that are most relevant to the regimes for 
SEA and EQIA. ${ }^{116}$ The initial approach of the courts to the discretion of decision makers in the process of EIA has been described as follows:

"The courts are deferential to executive discretion provided that it has some rational basis and does not violate what the court regards as widely accepted standards of morality." 117

This is perhaps best demonstrated by the case of $R \mathrm{v}$ Poole Borough Council ex parte Bee Bee. In this case the local council granted itself planning permission without any consideration of the need for an environmental impact assessment, but the Court refused to quash the permission on the grounds that when the local council made the decision it had all the relevant information before it that would have been contained in an environmental statement.

This approach was particularly lamentable in the context of EIA because the law should be interpreted in the light of the purpose of the Directive. There was however, little evidence of this in the early years of EIA. ${ }^{118}$ The procedural nature of EIA should not necessarily however, invoke this response from the courts.

“. . . liberal principles do not require the courts to be deferential in respect of 'process' matters. The courts should be able to ensure that the information provided is sufficient, that the viewpoint of all interested parties is given equal opportunity and that an assessment is carried out in the manner contemplated by the Directive." 119

A very different approach has however, been adopted more recently by the House of Lords. The case of Berkely is now the leading decision in this regard. This involved an application by Fulham Football Club to build a new stadium, incorporating and improving listed buildings, and to finance the project by building a block of flats on the boundary. The planning application did not include an environmental statement despite acknowledging that there was some disagreement between environmental organisations as to the effect of the building work on the adjacent river Thames. The House of Lords refused to accept that it was possible to retrospectively dispense with requirements of the EIA regulations on the ground that the outcome would have been the same or that the local planning authority or Secretary of State had all the information before them. Hence, in this case where the relevant information was in the public domain but would take a substantial amount of time to track down, the court stated that such a 'paper chase' was not equivalent to an environmental statement.

"The point about the environmental statement contemplated by the Directive is that it constitutes a single and accessible compilation, produced by the applicant at the very start of the

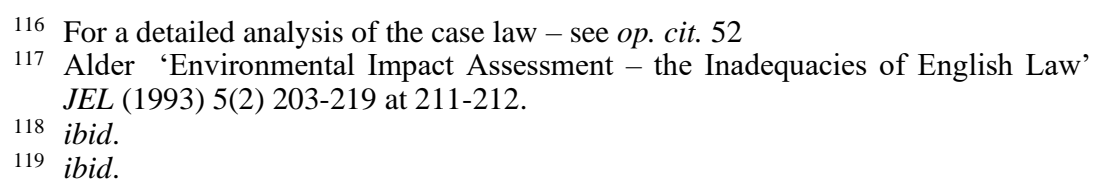


application process of the relevant environmental information and the summary is in non-technical language." 120

In reaching its decision the Court highlighted the importance of the consultation requirements within the procedure.

"The Directive requires not merely that the planning authority should have the necessary information, but that it should have been obtained by means of a particular procedure, namely that of an EIA ... an essential element in this procedure is that ... the environmental statement by the developer sould have been made available to the public and that the public should have been given the opportunity to express an opinion." 121

This new approach would be certainly be welcome in respect of the enforcement of the SEA regulations. However, since the judgement in Berkely there appears to be something of a retreat from this approach, by the Court of Appeal, at least in respect of the screening process. In the case of Younger Homes the Court of Appeal was prepared to accept as evidence of a screening opinion a letter stating that the opinion had been made because the actual evidence of the opinion, which was in fact made in a handwritten note, had since been lost.

With regard to the question of the public authority's judgement of the "significant" impacts of a proposal the approach is similarly to defer largely to the discretion of the decision maker. This question is considered to be a question of fact and even if there is some uncertainty as to the possible impacts on the environment, the decision as to whether or not to carry out a full environmental assessment is left entirely to the discretion of the decision maker subject to the Wednesbury principle. ${ }^{122}$ The judgement regarding the signficance of the effects upon the environment is indeed a very complex one:

"A judgement about the potential significance of an impact includes several elements, in particular consideration of the receiving environment and intensity of the impacts including cumulative change. Context is therefore vitally important in judgements about signficance." 123

The deference of the courts to the discretion of the decision maker is, therefore, logical. It should however, be accompanied by a robust view of the need for vigilance in following the procedure of EIA as outlined in the Berkely case and in respect of the quality of the environmental statement. The latter has been demonstrated in the case of Sweet in which the Court of Appeal refused to accept an environmental statement made without any "significant professional involvement" resulting "in a document that is poorly presented and lacking in certain matters of fundamental importance in

120 Berkely v Secretary of State for the Environment Transport and the Regions and Fulham Football Club (Berkely No. 1) [2000] 3 WLR 420.

121 ibid.

${ }^{122} R$ (Malster) v Ipswich Borough Council and Ipswich Town Football Club [2001]All ER (D) 107 And R (Jones) v Mansfield District Council [2003] EWCA (civ.) 1408 discussed in detail in op. cit. 52 at 123-127.

123 Op. cit. 52 at 103. 
assessing the likely impact of the proposed development of the surrounding area." In the context of SEA however, the environmental statement will be created by a central authority and, hence, the court may be more reluctant to intervene.

The case law on EQIA, as outlined below, includes a number of cases in which the court has referred to the definition of equality of opportunity. In the context of EIA however, the notion of environmental damage has proved much less contentious. One such case however, is that of Malster. This involved an application for the redevelopment of the North Stand at Ipswich Town Football Club's stadium. The complainant was concerned about the shadowing effect that would be created by the new stand. The High Court considered that:

"The 1999 regulations are concerned to protect the environment in the public interest. Whilst this may have the effect of avoiding harm to residential amenity, the purpose of the 1999 regulations is not to protect the amenity of individual dwelling-houses." 124

In the Court of Appeal a request to refer the question of the extent and meaning of the term environment to the European Court of Justice was refused. ${ }^{125}$

\section{Equality Impact Assessment}

As outlined above, a number of cases regarding section 75 Northern Ireland Act 1998 have been concerned with the definition of equality of opportunity. Most of these have focused on the issue of religious and political discrimination, ${ }^{126}$ but there are some examples of cases regarding other forms of discrimination. In fact, the most contentious litigation in this field has arisen in respect of discrimination on the basis of age. A series of cases have thus been brought in relation to the process of creating legislation on AntiSocial Behaviour Orders (ASBOs), all of which have focused on the basic issue that insufficient attention was given to the impact of such legislation on young people.

Three possible approaches to the meaning of equality of opportunity in this context have been identified:

"The first perspective is to view section 75 as essentially another piece of anti-discrmination legislation. In particular, this perspective views section 75 as not about outcomes, as

124 Malster op cit 122 at 73.

125 "I accept that situations could arise in which the point which it is sought to raise, the severe effect on a limited area, might involve a reference to the court for guidance as to how the Directive should be construed. In my judgement that does not arise upon the present facts." Pill LJ at para 20.

126 For instance, in the case of Connor Murphy a review was brought in respect of the decision of the Secretary of State for Northern Ireland to introduce regulations that required the flying of Union Jack flag on government buildings. It was found that "the flying of the Union flag is not designed to favour one tradition over another; it merely reflects Northern Ireland's constitutional position as part of the UK." Re Connor Murphy (High Court) 4th October 2001. 
being about persons rather than groups, and not being about affirmative action... The second perspective views section 75 as broader than anti-discrimination approaches, imposing a positive obligation on public authorities but one that essentially concentrates on achieving fair procedures and is unconcerned with outcomes...The third perspective views section 75 as centrally concerned with outcomes and is radically more egalitarian than either of the first two..."127

The courts' initial approach was based very much on the first of these perspectives, but some progress appears to have been made in the recent case of Neill. The judgement in Neill followed the case of Re Northern Ireland Commissioner for Children and Young People which involved an application for leave to review of the decision of Secretary of State to put legislation before Parliament on Anti-Social Behaviour Orders (ASBOs). ${ }^{128}$ The Commissioner for Children and Young People argued that this legislation would have a particularly important and negative impact on young people, and that equality of opportunity should be interpreted to include the opportunity not to be disadvantaged. The High Court held however, that the legislation in question would apply to everyone in the same way; Girvan J stating that "All are free to obey the law". Not only does this approach go no further than a negative interpretation of non-discrimination rather than a positive duty but arguably, puts the emphasis when examining adverse impact on the reasons for the impact and motive for introducing the policy rather than the outcome of the policy. The implicit conclusion from the judgement is that criminal or quasi-criminal matters would fall outside the scrutiny of section $75 .{ }^{129}$

The first instance decision in Neill was a related case brought on the grounds that the Northern Ireland Office (NIO), the body responsible for implementation of the legislation and policy, had failed to fulfil its statutory duty under section 75 by not carrying out an EQIA. The same arguments regarding the definition of equality of opportunity were raised in Neill and Girvan $\mathbf{J}$ responded differently, qualifying his previous decision. He now concluded that by finding that "All are free to obey the law", he had overstated the position and noted that the concept of equality of opportunity in the Northern Ireland Act 1998 derived from the Good Friday Agreement. Although the term is not defined in the Act, it is clear from the Agreement that it is intended to cover both the social and economic life of individuals. ${ }^{130}$ A criminal or quasi-criminal matter regulating the social lives of individuals may potentially have an adverse impact on one or more of the disadvantaged groups protected by section 75 . It is necessary to consider the policy stage of such legislation rather than simply to say that "once the law is enacted and the action is criminalised an individual from one of the affected groups can

Op. cit. 63 at 14-15.

(QBD) 2004 NIQB 40 (23rd June 2004).

129 As argued by Counsel for the appellant in Neill. In the matter of an Application by Peter Neill for Judicial Review [2005] NIQB 66 at para 47 and see Briefing Note by the Committee on the Administration of Justice on the section 75 Challenge (2005).

130 ibid., Girvan $\mathbf{J}$ referred to the analysis of the introduction of the concept in the Good Friday Agreement by McCrudden in op. cit. 96. 
have no grievance because he is simply bound to obey the law."131 Hence, though the court has rejected a legal duty on public bodies to ensure due regard to equality of outcomes, in carrying out its policies they must have due regard to potential adverse impact, not merely less favourable treatment when the policy is made. Nor can a public body argue that the reason for the adverse impact is relevant to its decision to screen in or screen out policies for impact assessment.

In the context of EQIA, the duty on public bodies under section 75 is to produce an equality scheme which must outline how they intend to assess and consult on the likely impacts of policies. Few of the cases considered so far have dealt directly with the duty to make arrangements for PIA as laid down in Schedule 9 to the Act. ${ }^{132}$ The Court did however, refer to the duty to ensure "meaningful consultation" in the case of Re Northern Ireland Commissioner for Children and Young People. Somewhat worryingly for advocates of children's rights, Girvan J noted the limited ability of children to be involved in "meaningful consultation." 133 This argument could be used to support a lack of consultation with other groups such as those with learning or communication difficulties. Although the statement by Girvan J did not relate directly to section 75 , it is hoped that public bodies do not use it as a basis for limited consultation.

The relationship betwen the Equality Commission complaints procedure and the role of the courts in judicial review has also been dealt with in the Neill litigation. At first instance, Girvan J considered the structure of section 75 and concluded that by establishing a complex complaints procedure Parliament intended that "alleged breaches of schemes are to be the subject of investigation and reporting with political consequences" and did not intend to confer rights to be assessed by "litigious means". ${ }^{134}$ On appeal however, it was argued that Girvan $\mathbf{J}$ was effectively imposing an ouster clause on the section which was not explicit therein, and that although the complaints procedure was intended to be the main remedy for a breach of an equality scheme it was not the sole remedy. ${ }^{135}$ The Court of Appeal dismissed the case, agreeing with Girvan $\mathrm{J}$ that "the juxaposition of sections 75 and 76 with contrasting mechanisms...strongly favours the conclusion that parliament intended that, in the main at least, the consequences of a failure to comply with section 75 would be political." ${ }^{136}$ However, the Court of Appeal accepted that there may be occasions where judical review is available. It did not wish to hypothesise on such situations, but suggested that they be dealt with on a case by case basis. ${ }^{137}$ As the case was dealing with a procedural point, it could be argued that such a case may arise where a public

131 ibid.

132 [2004] NIQB 64 1st October 2004.

133 Op. cit. 128.

134 Para.42 op. cit. 129.

135 Robin Allen QC, Counsel for CAJ in intervention in Neill judgement op cit 129 and the Briefing Note op cit 129. The intervention also noted that the question of non-justiciability in similar legislation in Great Britain had not arisen, e.g. s.71 Race Relations Act 1976 and s.404 Greater London Authority Act 1999.

136 [2006]NICA5 para.29.

137 Para.30 ibid. 
body failed substantively to fulfil the equality duty, such as putting in place an EQIA and then failing to follow it.

\section{The Complaints Procedure}

The Equality Commission is responsible for receiving complaints and dealing with them in a "quasi - judicial" function. It is important to note that the procedures are only open to alleged failures to comply with a part of the equality scheme drawn up by the authorities and not with a breach of the general duty to promote equality of opportunity under section $75(1) .^{138}$ The statutory guidance specifically states however that the former includes the failure to carry out the key elements of equality impact assessment which may amount to a breach of the equality scheme. ${ }^{139}$ There are two different types of procedure. Under paragraph 10 of Schedule 9 to the Act the Equality Commission may bring a case on behalf on an individual that has been "directly affected" and under paragraph 11 of Schedule 9 the Equality Commission may bring a complaint of its own volition.

In relation to paragraph 10 investigations, the key issue is the definition of people "directly affected" by the equality scheme. ${ }^{140}$ This issue was once again raised in the Neill judgement, as a complaint had been made to the Equality Commission by the Children's Law Centre (CLC) under the Para 10 procedure. ${ }^{141}$ The Northern Ireland Office (NIO) responsible for introduction of the orders, argued that the CLC was not directly affected by the measure because the term "directly affected" should be construed more narrowly than the traditional judicial review test of "sufficient interest". Girvan J agreed, stating it was clear that the CLC could never be a party to an ASBO. The fact that the NIO raised the issue of standing in this case has been criticised as an attempt to fetter the discretion of the Equality Commission and so undermine its work, as queries by public bodies of every aspect of an investigation will "tie the Commission in legal knots"142 and lead to an "arid legal formalism." 143 However, Girvan J did note that any challenge on this ground would be likely to fail as the Equality Commission can opt to carry out its own investigation under Para 11 and, in most cases, would chose to do

138 Sch.9 paras.10(1) and 11(1) op. cit. 57.

139 Annex 1 op. cit. 60

140 Sch.9 para.10(2) op. cit. 57.

141 Op. cit. 129.

142 Briefing Note op. cit. 129 at 2. The Note also pointed out that constant challenges made against the investigatory powers of the Commission for racial equality in Great Britain undermined its work in the 1990s.

143 Robin Allen QC, Counsel for Committee for the Administration of Justice (CAJ) in intervention in Neill judgement quoted ibid. Also note, the NIO contended in court that challenges could not come from representative of directly affected groups but that the Police Service of Northern Ireland (PSNI) could make a complaint. As the CAJ Briefing Note pointed out, to argue that the PSNI may make a complaint about a policy it will be responsible for implementing and consultees cannot, would suggest an undermining of the spirit and purpose of the equality duty. It should also be noted that the Children's Law Centre was recognised as a consultee for the purposes of screening by the NIO. 
so if a meritorious complaint was brought by someone not "directly affected."144

Once the Equality Commission has decided to bring a complaint, whether under paragraph 10 or 11, the first step is to put in place measures to attempt to deal with the complaint informally by conciliation with the authority in question. This encourages a collaborative approach and although there are no publicly available figures as to how many complaints are dealt with informally, the cooperative model seems to be working to the extent that there is little evidence of a refusal by public bodies to accommodate the Equality Commission's findings, with the notable exception of the ASBOs case.

Where a formal investigation is carried out the Equality Commission adopts an inquisitorial approach and sends its report to the parties, the Secretary of the State and the Assembly. If the Authority fails to comply with the recommendations, the Equality Commission may ask the Secretary of State to issue directions to the Authority. ${ }^{145}$ Few cases have involved a formal investigation by the Equality Commission and to date, the results of only ten investigations have been published. ${ }^{146}$

The latest Equality Commission report states that overall, the number of complaints remains small but that the numbers are growing. ${ }^{147}$ There is currently a lack of evidence on which to make any reliable conclusions about the success of the complaints procedure. ${ }^{148}$ However, there is certainly some

144 The Chief Commissioner of the Equality Commission has also stated he does not believe that the judgment on the definition of the term "directly affected" in Neill will hamper the investigatory powers of the Commissioner given its wider remit under para.11 (Bob Collins, Chief Commissioner, Equality Commission for Northern Ireland, speech delivered at a Conference held by the Human Rights Centre, School of Law, Queen's University Belfast The Nature, Impact and Future of Section 75 Northern Ireland Act 1998 (2006))

145 Sch.9 para.11 (2) - (5) op. cit. 57.

146 Of these, seven involved paragraph 10 investigations and three were paragraph 11 investigations. The paragraph 10 complaints involved complaints about failures to screen, failures to carry out a proper EQIA, failures to consult and failures to respond to complaints. Out of these cases, the Equality Commission found a breach of the equality scheme in five cases and either recommended action, such as an EQIA, or made no recommendations as the public body had agreed to re screen or improve procedures. The Equality Commission found a breach of an equality scheme in one case where the public body had failed to carry out external consultation on a policy affecting provision for children with "special needs" (Don Leeson and Department of Finance and Personnel (SD1/04/04). The Department agreed to improve its complaint procedures relating to Section 75 . The paragraph 11 investigations involved screening and consultation e.g. Belfast Education and Library Board (SD1/01/04) in which no recommendations were made as the Board agreed to modify its consultation procedures. Notably, in three cases involving paragraph 10 investigations, the matter also went to judicial review (including the ASBOs litigation). See further Equality Commission website at http://www.equalityni.org/publications/downloadlist.cfm?id=17.

147 Equality Commission NI Report on the implementation of the Section 75 Equality and Good Relations Duties by Public Authorities 1 April 2003 - March 2004.

148 The Equality Commission is currently carrying out its five year review of the operation of S.75, which included examining compliance and enforcement issues. 
evidence of dissatisfaction among consultees (specifically community and voluntary groups) with the responses from public bodies when complaints are made; in particular concerning the length of time taken to respond and the use of "legal jargon". ${ }^{149}$ The Equality Commission has also noted the lack of information it receives from public bodies about informal/formal complaints made and what effect these complaints have, if any, on policy. Statutory compliance is however, only one part of the Equality Commission's legal work and to be more effective, it may need to target investigations at specific issues relating to the achievement of equality of opportunity. ${ }^{150}$

\section{Summary}

The key issue in the case law surrounding section 75 of the Northern Ireland Act 1998 has been the definition of the term 'equality of opportunity'. Definition is far less of an issue in relation to EIA and SEA which focus on environmental assessment as a tool for the achievement of sustainable development. This serves to highlight the difficulty of ensuring a clear understanding of objectives such as equality of opportunity and sustainable development. Recently the courts appear to be moving towards an acceptance of equality of opportunity as a positive duty rather than viewing it in the restrictive terms of anti-discrimination. This issue is vital to the success of this regime that seeks to move away from the narrow vision of previous anti-discrimination legislation. The case law also highlights the importance of the context in which it was introduced. The courts in Northern Ireland have recognised the importance of the context of devolution in Northern Ireland and the Good Friday Agreement whilst the case law on EIA demonstrates a growing acceptance of the need to interpret UK legislation in the light of the purpose of the EU Directive. ${ }^{151}$

Whilst recognising the necessary discretion of decision makers in carrying out impact assessment the courts should be able to ensure that the procedure is adhered to at every step. This approach has recently been realised in relation to EIA and it is hoped that it will be extended to SEA. In particular, it is important to protect the public's rights to consultation under these regimes. Issues such as the question of "meaningful consultation" and the quality of the impact statement are really substantive questions although the courts have touched upon them both. However, in the context of EIA, questions of the significance of environmental impacts in both the screening and scoping process are considered to be questions of fact for the decision maker. The courts in Northern Ireland have yet to consider the issue of assessing adverse impact but are likely to adopt a similar approach.

Following the judgement in Neill, matters of process in respect of EQIA have largely been assigned to the Equality Commission's complaints procedure. Legal accountability is superseded by this process based on political accountability. Nevertheless, the court in Neill has accepted that recourse to

149 Op. cit. 148 at 13.

150 See McLaughlin and Faris op. cit. 100.

151 See Robinson v Secretary of State for Northern Ireland [2002] 32. The court underlined the importance on the context of the Good Friday Agreement and Northern Ireland Act as part of a constitutional settlement. 
the courts may be appropriate in some circumstances. This approach is to be welcomed because such cases will serve to highlight the worst infringements of the process..$^{152}$

\section{Conclusions}

The introduction of 'hard law' in respect of policy impact assessment has parallels with wider moves towards the juridification of the political process in British constitutionalism. ${ }^{153}$ This is exemplified, most notably, by the introduction of the Human Rights Act 1998 that protects civil and political rights. This Act has been criticised for the way in which it excludes social equality and it may also be argued that a bill of rights should include a "right to a clean environment." 154 In this context, regulation in respect of policy impact assessment can be seen to 'fill the gap' in protecting fundamental social values such as equality and sustainable development. This also raises a number of important questions about the most effective means of providing accountability in attempting to regulate decision making in government. Providing accountability through the courts is not of course without difficulty because of the problems of the cost and time involved in litigation. Furthermore, in the context of equality it has been argued that an overly litigious approach could lead public bodies to become defensive, uncooperative and overly bureaucratic. ${ }^{155}$ The political context will also always be important to the success of any legal regime of this nature because of the level of discretion that government decision makers retain. However, a "litigation strategy" can be used to focus the attention of public bodies on their duties under the law as well as highlighting the importance of equality issues within wider civil society. ${ }^{156}$

The EQIA model adopts an approach based on both legal and political accountability by incorporating a complaints procedure to be operated by the Equality Commission. The inclusion of a complaints procedure is particularly important in the historical context of Northern Ireland to ensure that complaints will be aired and dealt with in the political arena. The intention is to encourage a triangular approach between public bodies, the Equality Commission and consultees/complainants. In this way the promotion of equality of opportunity is collaborative rather than adversarial and so lends itself to the concept of participatory democracy. Although this process is still very much in its infancy, both the courts and academic commentators argue that this is the preferred model. ${ }^{157}$

The alternative is to rely on a process of audit albeit subject to internal or external review. The models of audit that have arisen so far have proven to be less than effective but that is not to say that a more rigorous approach

152 Op. cit. 63 at 74.

153 See for example, op. cit. 5 at 382-389 and generally see the various essays in Jowell and Oliver The Changing Constitution (2004).

154 See further Ewing "The Unbalanced Constitution" in Campbell Sceptical Essays on Human Rights (2001) 103-119 and Hayward Constitutional Environmental Rights (2005).

155 McLaughlin and Faris, op. cit. 100 at 36

156 Op. cit. 63 at 74.

157 See McLaughlin and Faris, op. cit. 100 and Donaghy, op. cit. 99. 
could not be achieved. This has been demonstrated in relation to financial audit for many years. It is certainly true that a process of audit in relation to the quality of impact assessments would be widely welcomed to provide some accountability in terms of the substantive quality of the process. This may be subject to an internal review process but this would lack any real teeth without high level political support. It is probably therefore, best carried out by an independent review body. Under the EQIA process, the Equality Commission would be the obvious body to carry out this task but this would be extremely resource intensive and is thus unlikely at this stage. Nevertheless, the conclusion of this paper is that the most effective means of providing accountability in the impact assessment process is to adopt a three pronged approach based on political and legal accountability, as in the example of EQIA, as well as an audit process in respect of the substantive quality of assessments. ${ }^{158}$

If we are to include regulation within this model, it is also important to ensure that the legal framework itself supports an effective process. The comparison of SEA and EQIA above appears to suggest that we have now reached a stage in which it is possible to provide a "best practice" model of policy impact assessment that might be applied in any field. The important question is to what extent we wish to continue developing such regimes in individual fields or would wish to develop a model of integrated impact assessment. From a practical point of view integrated impact assessment has great appeal and will meet the criticisms of decision makers with regard to overlapping duties. ${ }^{159}$ However, there is a real danger that if too many issues are included the process of policy impact assessment will lose its value as decision makers and citizens fail to understand or take on board the individual objectives. ${ }^{160}$ This may be an argument for focusing on a few key issues that are considered most fundamental to society outside the sphere of

158 Community and voluntary groups have suggested that government inspectorates and the NI Audit office could be involved in monitoring Section 75 which would lead to more uniform and improved implementation. See Equality Commission Report op. cit. 100 at 10.

159 E.g. under the Northern Ireland Act, S.75(2), public authorities also have a duty to have regard to good relations between people of different political opinion, religious belief and racial groups. Research is ongoing as to how this lesser duty (equality is due regard) is being implemented. The OFMDFM of the NI assembly in the report "A Shared Future" Policy and Strategic framework for Northern Ireland" (March 2005) stated that "A systematic assessment of the good relations impacts of new (or reviewed) policies and legislation will be introduced across departments. This will require departments, as part of integrated impact assessments, to assess the impact of proposed policies on the promotion of sharing, in a similar way to which policies are currently assessed for their impact upon equality and the targeting of social need" The Targeting Social Need (new TSN) programme is a non-statutory duty on public bodies in Northern Ireland to target resources at deprived areas.

160 E.g. an audit of the good relations duty carried out by the Equality Commission found that whilst in some areas good progress was being made with audits and programmes being put in place, other public bodies stated that the duty was part of an equality scheme and not reported on separately or that the body had been concentrating on equality impact assessments and not on the specific good relations duty. Equality Commission Audit of progress on the Good Relations Duty 2000-2003 
civil and political rights protected by the Human Rights Act 1998. There is a clear argument for including both equality and sustainable development as core values in society. ${ }^{161}$ Indeed, as outlined above, it can be argued that equality is an essential element of sustainable development. Sustainable development has certainly been the focus of 'soft law' approaches to integrated impact assessment to date. Sustainable development however, is an exceptionally difficult concept to define and has proven difficult to operationalise. ${ }^{162}$ In contrast, the courts in Northern Ireland appear to be rising to the challenge of defining equality of opportunity which does appear more concrete. ${ }^{163}$ The best approach is to continue to focus on impact assessment for environmental protection and equality as two core values. Thus, the "best practice" model of impact assessment should be extended to policy level in the field of environmental protection and adopted in EQIA throughout the UK.

161 It could be argued that the good relations duty in Northern Ireland and the nonstatutory duty with regard to new TSN are integral to the achievement of greater equality outcomes under S.75."Good relations cannot be based on inequality between different religions of ethnic groups. Social cohesion requires equality to be reinforced by good community relations." Dr. Marjorie Mowlam, Secretary of State for Northern Ireland, House of Commons, Official report, 27 July 1998. The revised Statutory Guidance makes it clear that although equality is the primary duty under the Northern Ireland Act, recognition of the interdependence of the two duties is crucial. Equality Commission for Northern Ireland Section 75 of the Northern Ireland Act 1998: Guide to the Statutory Duties (2005) para.2.14

162 See for example criticisms of the Welsh Assembly Strategy for Sustainable Development in Flynn Living Differently? An Assessment of the First Four Years of the Welsh Assembly Government's Sustainable Development Duty (2003).

163 Op. cit. 132. 